\title{
Motivations and Barriers of the Model of Non-Traditional Market Economy: A Case to Study in BRICS
}

\author{
Nguyen Tan Phat \\ University of Economics and Law, Vietnam National University HCMC, Ho Chi Minh City, Vietnam \\ Email: ngtaphat@yahoo.com
}

Received August 29, 2012; revised October 7, 2012; accepted October 17, 2012

\begin{abstract}
Emerging economies including Brasil, Russia, India, China and South Africa known as a growing force with the power of economy, finance and enormous potentials are considered as massive motivations affecting greatly the rest parts of the entire world. Theirs characteristics of politics, political geography and economic policy are not identical to traditional market economies in Europe and the US BRICS can be called the model of non-traditional market economy. The rise and the great effect of BRICS can change the order of the current world which has long been dominated by western nations during the past 2 decades. However, BRICS itself contains challenges and barriers for the socio-economic development such as hot growth, poverty, low living standards and environmental pollution, etc. The political affiliations and violence in declaring the sovereignty of seas, islands and territory reveal the latent unstability that can drive to conflicts and arms race, etc. Brics is a force without lack of necessary motivational factors that can enhance the development but also contain inside challenges and barriers for the rest parts of the modern world.
\end{abstract}

Keywords: BRICS; Traditional Market Economy; Non-Traditional Market Economy; Motivations; Barriers

\section{Introduction}

Most nations nowadays comply with the model of market economy but have 2 distinct operations. One is the model of traditional market economy in western countries and developed nations in Northeast Asia like Japan, Korea, Singapore, Hongkong and Taiwan. The other operates according to the non-traditional market economy in emerging nations like Brasil, India, China and South Africa called BRICS group.

The 2008 global financial crisis destroyed severely the finance of western countries that have obeyed traditional economy and public debt has overwhelmed the whole Europe. In the early 21 st century appeared the rather violent rise of the non-traditional economies, namely BRICS, which have had a pervasive influence not only on economics but also on global political issues.

The appearance of BRICS and its growing impact is regarded as a ruler for the imperfection of non-traditional model the theories of which must be reconsidered to have a more convincing explanation of its imperfection and inefficiency when facing modern economic problems. This appearance is also expected to supplement the limited aspect of this model, so BRICS has become vital for the rest parts of the world due to the world's largest population, the second largest in economics just after the US and the place that frequently provides the world with natural resources. However, is BRICS perfect? Abso- lutely no. BRICS itself is confronting numerous serious problems and its actions are worrying much many other countries.

\section{Reviewing Theories of the Model of Traditional Market Economy and Its Inefficiency towards the Current Economic Issues}

The operation of this economy obeys the discourse on method and the thoughts of the 2 most remarkable scientists, Adam Smith and John Maynard Keynes.

The thoughts and discourse on method of Adam Smith (1723-1790) in resolving issues of free market economy in the 18th century and its influence until the present time.

Despite the fact that economic issues and principles had been written a lot before Adam Smith, most people considered him the Father of economics. He was given such an honor owing to the recognition of capital market economy as an economic system that made the entire people become rich. He was the first seeing benefits from more competitiveness and had arguments in favor of policy that enhance competitiveness, which requires State's less intervention into the economy but takes proper measures to prevent exclusiveness. It comes from the thought and discourse on method about market economy of Adam Smith. This characteristic has become 
the truth for the model of traditional market economy. The praise of individual benefits when human's economic activity brought richness to capitalists and by chance brought benefits for the community itself, which went beyond the original intention under the guide of an invisible hand. Such recognition has been lasting through the centuries and has come the predominant thought encouraging business production activities and promoting the abruptly rapid growth of capitalism in the pharse of free competitiveness. It was believed as the period of the glorious evolution of a new production method and radical thought. His thought coincided accidentally with practice, doubling the development on the basis of eliminating the old feudal relation so as to set up a novel socio-economic structure named capital market economy with an auto-adjustable market mechanism reliant on objective principles of economics. Thus, all economic activities must be on the foundation of free competitiveness without State's intervention [1].

Adam Smith's thought and his method kept on being backed by the New Classic, especially the theory of General Balance of Leon Waras and the new Liberalism and later became the legal principles of international financial institutions such as WB, IMF, WTO, etc.

Yet Adam Smith could have had the second thought if he had witnessed the exclusiveness of capitalism, economic crises since the early 19 th century and particularly the self-interests of operators in financial corporations which triggered financial corruption and the incredible abrupt collapse of the 2008 financial crisis. The fact that personal gain of economic human factor in Adam Smith's theory was distorted to turn into the global financial corruption beside the uncontrolable fiscal deals becomes an enormous challenge of the 21 st century.

The thoughts and discourse on method of John Maynard Keynes (1883-1946) in dealing with market economic problems in the crisis period.

John Maynard Keynes was seemingly born in order to save the market economy out of massive economic crises thanks to the direct interference of State into the economy to stimulate investment and consumption, creating employment, income increase, and economic growth.

Financial and monetary policies as incentives of consumption and investment fuel economic development produce jobs and curb unemployment. Welfare policies such as tax relief and an increase on unemployment allowance and health insurance, etc. are really vital for people when crises occur. So, The General theory of employment, interest and money of Keynes, the core of which is the role of State in solving economic crises and ensuring the macro balance is believed as an economic guidebook towards politicians, businesspeople and schoolars during the crises and post-economic crises.

Keynes's measures really work in case a crisis erupts in the capital market economy. The theory is high-applied in dealing with crises not only due to the content of its thought and the characteristics of his discourse on method but also due to the macro tools and the relatively perfect financial institutions that create a material premise in practice when being performed [2].

- Changes that askew the orbit of traditional market economy to shape the non-traditional market economy.

+ Consequences from the general principles of Adam Smith's discourse on method.

Once basic principles of traditional market economy become general rules for pledges and international normal practice in trading, investment, finance, and forming international institutions like WB, IMF or WTO, etc., to regulate the global economy, problems arise in terms of such general principles. Financial corruption, environmental pollution, devaluation of domestic currency, trade fraudulence or economic speculation etc., are the results of economic human factor-personal benefits are put the top but severely ruin the society. Restricting it is a mathematics problem that could hardly find the answer because with a correct answer, it is obligatory that parameters (general principles) be changed, which could upset entirely the whole system and global principles.

As a result, many countries have to return to trade protectionism, curb investment and control finance, etc., while on the traditional market economies themselves to overcome such difficulty.

+ The consequences of monetary and financial tools in Keynes' discourse on method.

As the above-mentioned analysis, one of the factors that make Keynes' application fast and powerful is financial tools (tax and government's expenditure in the form of investment), currency (interest and open market skills), and organizations of credit and finance. Yet there has been a too rapid growth of banks and such organizations with a great deal of radical, strange, diverse and unmanageable credit business in the 10 recent years. This system has gone beyond its conventional functions, generating an outbreak of investment and speculation on the sensitive markets such as petroleum, real estate, stocks and insurance, etc., hence an artificial demand-supply and inevitable crises. Financial crisis, in fact, is melting the cream layer of economic crisis. The virtual values of risky investment and speculation shown on the outside cover layers of stocks or mortgage credit break and get back to the true value of the economy. While some banks and leading American-European financial organisations went bankrupt or needed urgent assistance to get out of the collapse, car manufacturers also sent signals of immmediate help. The fact that economic crisis in which financial crisis is the first starting-point of the system then spreads to industries of auto manufacture and construc- 
tion material, etc., beside the luxurious spending for public sector and social welfare is the cause of crisis of public debt in Europe and makes it much more severe.

+ Consequences of the ties owing to the regional and international affiliation.

The wider regional and international link helps the market economy operate according to group benefits, but when troubles arise, it is hard to find out creative solutions due to the general principles. In contrast, it doesn't happen to the non-traditional market economy as there is no general rule in these nations.

For this reason, it is visible that the non-traditional model demonstrates itself an economic institution with a more clever and flexible use of the theories of Adam Smith, Karl Marx and John Maynard Keynes depending on specific circumstances. This unconventional institution reveals itself a more automatic system with swifter reactions, more tools yet less general principles [3].

\section{An Analysis of Figures and a Discussion of the BRICS Economic Model: Motivations and Barriers}

Political geographical location: The group of emerging economies-BRICS including Brasil, Russian Federation, India, China and South Africa-is in the 4 most important continents in the world. China and India are in Asia, Russia in Europe and South Africa in Africa. All nations of BRICS are located on top important positions in each continent and on crucial sea routes connecting Indian and Atlantic Oceans; Pacific and Indian Oceans; AtlanticIndian Oceans.

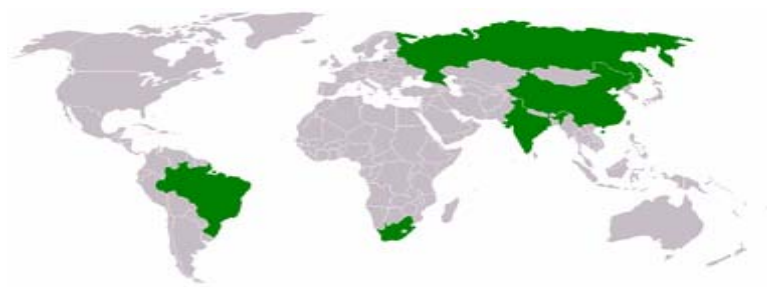

Map: BRICS' geographical location, Source: [4].

\subsection{Motivations}

Market and financial motivations for other nations.

The market power of BRICS is thanks to the world's largest population and the second biggest economy. According to the 2010 World Bank's figures (Table 1), BRICS's population was 29,496 million people, making up $42.78 \%$ of the world's population; the economic scale was 12.1 billion USD, accounting for $19.26 \%$ compared with the global economy, and just behind the US with 14.5 billion USD. The value of export goods was 2494953687243.75 USD, making up $16.67 \%$ of the whole globe, and the value of import goods

2123041584183.19 USD, $14.42 \%$ of the world. Import and export surplus was 371912103060.56 USD, 152.73\% bigger than the global surplus, which increased the total foreign currency reserves including gold and foreign currency by 4025 thousand billion USD, making up $37.37 \%$ of the world.

The motivation of high economic growth lasting in many years has promoted the pervasion to other related economies.

The statistics of the World Bank in the phase between 2002 and 2010 indicated that all members of BRICS had a speed of economic growth higher than the world's average speed. Among them are the 2 power houses, China and India, with 2.5 - 3.0 times higher than the world's average growth (Figure 1). The high and stable economic growth has helped the very great ability of accumulation, investment and purchasing power of the economies in BRICS.

In addition, most of them are trade surplus (Table 2) and possess a great deal of foreign currency reserves, which is an incentive for trade and finance of the entire world. The role of BRICS has specially become important towards the financial crisis and public debt in Europe, which has changed the face of financial economy and politics. Moreover, it has also modificated the structure being willing to buy government bonds, bank's bondsor stocks on financial markets. The voice of BRICS now seems to be more powerful in multilateral and bilat

Table 1. Norms of population, GDP and total foreign currency reserves of BRICS.

\begin{tabular}{cccr}
\hline \multirow{2}{*}{ BRICS } & Population & GDP & Total foreign currency reserves, gold and US dollars \\
\cline { 2 - 4 } & (Calculated unit: persons) & (Calculated unit: USD) & (Calculated unit: USD) \\
\hline Brazil & 194946000.00 & 2087889553821.68 & 479222291459.01 \\
Russian Federation & 141750000.00 & 1479819314058.23 & 300480145803.63 \\
India & 1224615000.00 & 1727111096363.26 & 2913711653593.96 \\
China & 1338300000.00 & 5926612009749.61 & 43819537259.82 \\
South Africa & 49991000.00 & 363910425627.97 & 4025918531676.06 \\
Total & 29496020.00 & 12185342399620.75 & 10773352665144.90 \\
The world & 6894594843.86 & 63256970222854.90 & $37.37 \%$ \\
Percentage compared & $42.78 \%$ & $19.26 \%$ & 370 \\
with the world & & &
\end{tabular}

Source: Calculated by the author from [5-7]. 


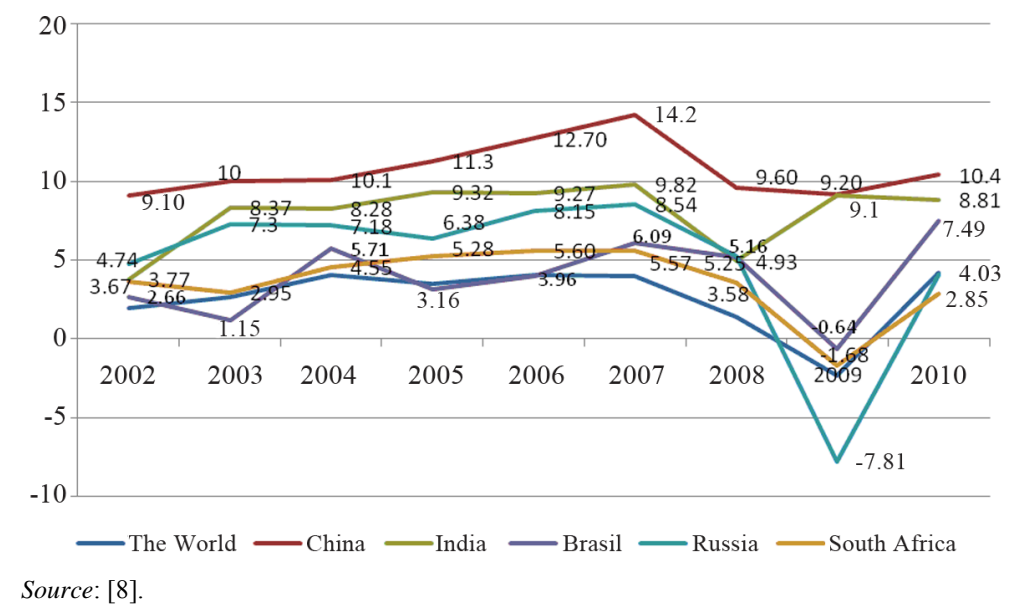

Figure 1. Speed of economic growth of BRICS and the world in the phase 2002-2010.

Table 2. Value of goods import and export in BRICS, 2010.

\begin{tabular}{cccc}
\hline BRICS & Export value (BOP, Current US\$) & Import value (BOP, Current US\$) & Import-export surplus \\
\hline Brazil & 201915285335.00 & 181768427438.00 & +20146857897.00 \\
Russian Federation & 400419230000.00 & 248738063000.00 & +151681167000.00 \\
India & 225501718165.03 & 323435448109.98 & -97903729944.95 \\
China & 1581417481957.48 & 1327237584592.67 & +254179897364.81 \\
South Africa & 85699971786.24 & 81862041042.54 & +3837930743.71 \\
Total & 2494953687243.75 & 2123041584183.19 & +371912103060.56 \\
The world & 14968765616569.10 & 14725261325258.00 & +243504291311.10 \\
Percentage compared with the world & $16.67 \%$ & $14.42 \%$ & $152.73 \%$ \\
\hline
\end{tabular}

Source: Calculated by the author from $[9,10]$.

eral forums.

Motivation of low production cost thanks to low-priced laborers and the profuse supply source of various kinds of laborers has stimulated manufacturing investment of international corporations in BRICS.

BRICS has a large population with low living standards, so low salary is an advantage of providing lowpriced labor force for developing countries. BRICS has become a gigantic construction site for the world's enormous manufacturers, producing a wide range of products from high-tech items like computer production, electronic components, automobiles to labor-intensive items such as garment and leather footwear, etc.

An advantage of resources export such as petroleum, gold, race earth and agricultural products to many countries and collecting a lot of foreign currency.

BRICS has the advantage of all kinds of natural resources and agricultural products with a big demand of consumption currently such as petroleum, gold (Russia), race earth (China), gold and diamond (South Africa), precious stones, coal, and rice (India), coffee, cocoa and timber (Brasil). Resources export has brought a great source of revenue for these nations and also become a tool in bargaining trade, economics and politics with other countries.

\subsection{Barriers}

Low incomes, impoverishment and social conflicts.

Among the nations in BRICS group, Russia and Brasil have per capita income as high as or a little higher than the one of the world. According to 2010 statistics from the World Bank, Russia made up $113.78 \%$ and Brasil was $116.73 \%$ compared with the averge income of the world. This rate was even much lower in nations with dense populations like India (15.37\%), China (48.26\%) and South Africa (79.34\%) (Figure 2).

Supposing that poverty standard is considered below 2 USD per day, the poor in India in 2010 would make up $68.72 \%$, equivalent to 829 million people. China, 2008, accounted for $29.79 \%$, equivalent to 394 million people. Brasil, 2009, 10.82\%, 20.9 million people. South Africa in 2009 was $31.33 \%, 15.42$ million people and Russia, 2009, $0.05 \%, 0.071$ million people. The overall poor population in BRICS was approximately 1259 million people, accounting for $18.26 \%$ of the world's total population in 2010 [11]. Thus, it is clear that the majority of the poor living on earth now chiefly concentrate in BRICS, except Russia. 
Living in the poverty is the root of social injustice disputes, crimes and illiteracy, etc. The exploitation of children and women laborers in hard coal mines, slumps, male chauvinism, HIV disease, environmental pollution and manufacture of counterfeit products, etc. are all in BRICS. This trouble is regarded as the most enormous barrier for social progress, civilization and democracy.

Energy for the demand of socio-economic growth is a challenge for BRICS. The electricity power consumed in 2009 accounted for $31.12 \%$ of the world's. Particularly, this rate in China was $61.21 \%$ of the entire BRICS and $19.05 \%$ of the global energy (Table 3).

It is remarkable that the increase speed of electricity consumption is higher than the average rate of the world, especially China. This pace in 2006 compared with 2004 in BRICS was $16.94 \%$ whereas it was $8.71 \%$ in the world, and particularly China was $30.14 \%$. The rate in BRICS was $16.02 \%$ in 2008 compared with $2006,6.72 \%$ in the world and $21.64 \%$ in China. $4.05 \%$ in 2009 compared with $2008,0.71 \%$ for the globe and China was $7.66 \%$ (Figure 3).

Despite the great volume of power consumption, it is hardly to meet the demand of socio-economic growth as the per capita output of consumption in BRICS nations

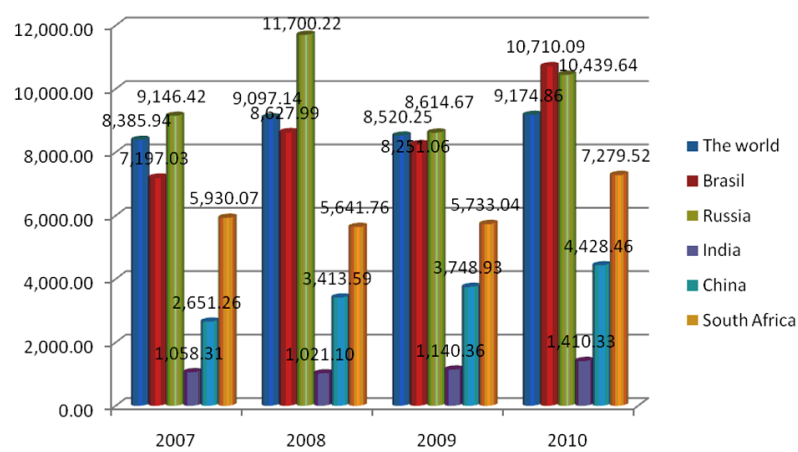

Figure 2. Per capita average income in BRICS and the world.

Table 3. Energy consumed in BRICS nations (Unit: million Kwh).

\begin{tabular}{ccccc}
\hline Years & $\mathbf{2 0 0 4}$ & $\mathbf{2 0 0 6}$ & $\mathbf{2 0 0 8}$ & $\mathbf{2 0 0 9}$ \\
\hline Brazil & 359,971 & 390,509 & 428,500 & 426,340 \\
Russia & 811.653 & 872.393 & 913.506 & 870.331 \\
India & 492.806 & 572.943 & 671.878 & 689.537 \\
China & 2055.968 & 2675.737 & 3254.152 & 3503.397 \\
$\begin{array}{c}\text { South Africa } \\
\text { Total }\end{array}$ & 217.066 & 228.964 & 232.230 & 223.520 \\
$\begin{array}{c}\text { The world } \\
\text { Percentage of }\end{array}$ & 15964.190 & 17355.506 & 18521.968 & 18390.614 \\
$\begin{array}{c}\text { BRICS compared } \\
\text { with the world }\end{array}$ & $24.66 \%$ & $27.31 \%$ & $29.69 \%$ & $31.12 \%$ \\
\hline $\begin{array}{c}\text { Source: [12] } \\
\text { Tin }\end{array}$ & & & & \\
\hline
\end{tabular}

Source: [12]. such as China, India and Brasil is lower than the average of the world and even much smaller than it is in developed countries like Japan, America, Singapore and Germany. In 2009, this average rate in India was $20.36 \%$ compared with the globe, and China was $93.87 \%$. But in comparison with the US, this ratio was just $20.37 \%$, $33.65 \%$ Japan, and $33.10 \%$ Singapore (Table 4).

China is growing fast, so the great energy sources are very in need whereas its petroleum sources are considered as the lowest among other countries and coal supply is also limited. Thus, it is the key reason for China to suggest arbitrarily and unacceptably the U-shaped line and trigger assaults on nations in the East Sea such as Vietnam, the Philippines, Japan Sea and Hwang Hai Sea with Korea.

Political connections, disputes and arms race in the whole globe.

Currently, the 2 nations of BRICS, China and Russia are permanent members of UN Security Council. The changing tendency of the world and diplomatic measures to reform the UN will be likely to focus mainly on expanding it by admitting India, Brasil and South Africa to

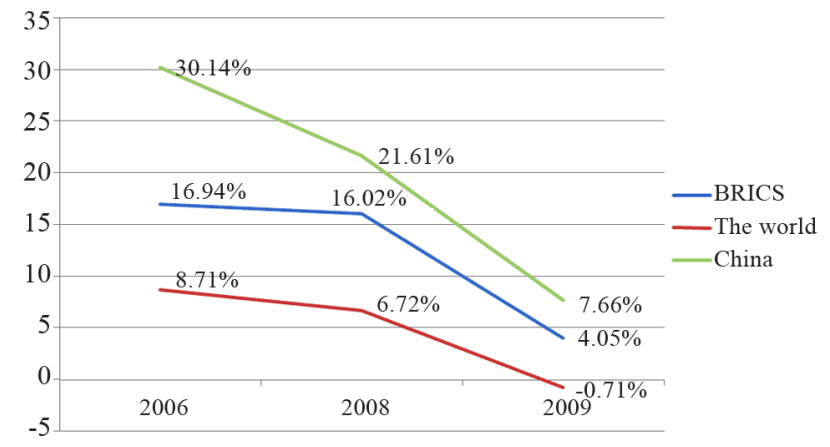

Source: Calculated by the author from [12].

Figure 3. Speed of energy consumption of BRICS, the world and China.

Table 4. Per capita energy consumed in BRICS in comparison with the globe and other nations (Unit: $\mathbf{k W h}$ ).

\begin{tabular}{cccccc}
\hline Year & $\mathbf{2 0 0 2}$ & $\mathbf{2 0 0 3}$ & $\mathbf{2 0 0 5}$ & $\mathbf{2 0 0 7}$ & $\mathbf{2 0 0 9}$ \\
\hline The world & 2425.24 & 2491.25 & 2656.17 & 2829.57 & 2803.23 \\
India & 400.26 & 417.49 & 455.86 & 539.48 & 570.93 \\
China & 1184.94 & 1379.38 & 1783.22 & 2329.26 & 2631.40 \\
Brasil & 1810.94 & 1884.10 & 2019.92 & 2174.94 & 2206.20 \\
South & 4527.37 & 4619.37 & 4703.90 & 4938.40 & 4532.02 \\
Africa & & & & & \\
Russia & 5304.66 & 5479.99 & 5784.97 & 6317.24 & 6135.57 \\
Japan & 7915.67 & 7815.31 & 8212.69 & 8489.65 & 7819.18 \\
The US & 13296.18 & 13307.49 & 13704.58 & 13657.45 & 12913.71 \\
Singapore & 7756.23 & 8113.64 & 8507.20 & 8513.71 & 7948.91 \\
Germany & 6900.78 & 6983.34 & 7113.41 & 7184.31 & 6778.66 \\
\hline
\end{tabular}

Source: [13]. 
this organization owing to their important roles in their own continents. The new growing axis of politics and militay is shown by the relationship between Russia and China; China-Russia and their partners in Latin America and Africa is revealed by the China's investment in most nations in Africa and Latin America, etc.

On the surface, the affiliation of BRICS is merely for their self-interests but each of the nations itself, even the neighboring nations like Russia, China and India, have had conflicts and envy of each other for history, economics and politics as well. Disputes at the thousandslong road border, charges against each other due to the support of protesters and the hatred of history are still problems that BRICS could hardly defeat.

\section{Conclusions}

Theoretical matters of the model of the conventional market economy and the general principles for international financial institutions such as WTO, WB, and IMF, are showing lack of efficiency upon confronting the modern economic problems such as the long-lasting financial crisis, public debt, inflation and unemployment.

In contrast, BRICS is typical of the unconventional economic model with the characteristics of economicpolitical institutions representing for countries with emerging economy. BRICS has had a wide effect on the face of economy and commerce owing to the world's largest population, and the second biggest economy after the US BRICS's power has been much enhanced since the 2008 global economic crisis and the European public debt, and currently they are seemingly more powerful thanks to the massive foreign currency reserves, the export of highvalued resources and labor-intensive products with low prices.

Besides, BRICS are confronting hard problems such as poverty, low living standards, environmental pollution and pressures of energy for growth. Moreover, the high rate of impoverishment but enormous foreign currency reserves is a paradox of development process, which reveals that BRICS fails to become an ideal model for the redistribution of wealth for community.

BRICS is attempting to show off their power by using non-traditional ways to solve economic issues, imposing to rob the sovereignty on the boundary, seas and islands of neighboring nations with vaguely and ambiguously historical arguments, and trying to create disputes regions so that they could force smaller countries to negotiate with them, otherwise they will use military strength to conquer them (a case in China now).

The fact that BRICS is establishing a new world order by the affiliation with economic-political-military policies that do not comply with international general rules is much worrying the modern world now.

\section{REFERENCES}

[1] A. Smith, "Wealth of Nations," W. Strahan and T. Cadell, London, 1776.

[2] J. M. Keynes, "The General Theory of Employment, IntErest and Money," Palgrave Macmillan, Hampshire, 1936.

[3] N. T. Phat, "Financial Corruption-A Challenge of Global Economic Security in the 21st Century," Economic Studies, Hanoi, 2010.

[4] The Wikipedia, "BRICS," 2012. http://vi.wikipedia.org/wiki/BRICS

[5] The World Bank, "Population, Total," 2012. http://search.worldbank.org/data?qterm=Population\&lang uage $=\mathrm{EN}$

[6] The World Bank, "GDP (Current US\$)," 2012. http://search.worldbank.org/data?qterm=GDP\&language= EN

[7] The World Bank, "Total Reserves," 2012. http://search.worldbank.org/data?qterm=Total\%20reserve \&language $=\mathrm{EN}$

[8] The World Bank, "GDP Growth (Annual \%)," 2012. http://search.worldbank.org/data?qterm=rate+of+Growth + GDP\&language $=$ EN\& format $=$

[9] The World Bank, "Goods Export (BOP, Current US\$)," 2012.

http://search.worldbank.org/data?qterm=Goods $\% 20$ Expor $\mathrm{t} \% 20 \% 28 \mathrm{BoP} \% 2 \mathrm{C} \% 20$ current\%20US\%24\%29\&languag $\mathrm{e}=\mathrm{EN}$

[10] The World Bank, "Goods Import (BOP, Current US\$)," 2012.

http://search.worldbank.org/data?qterm=Goos\%20Export $\% 20 \% 28 \mathrm{PoB} \% 2 \mathrm{C} \% 20$ current $\% 29 \&$ language $=\mathrm{EN}$

[11] The World Bank, "GDP per Capita (Current US\$)," 2012. $\mathrm{http}: / /$ search.worldbank.org/data?qterm=GDP\&language= EN

[12] The World Bank, "Electronic Power Consumption (kWh)," 2012.

http://search.worldbank.org/data?qterm=Electronic + powe $\mathrm{r}+$ consumtion + \&language $=\mathrm{EN} \&$ format $=$

[13] The World Bank, "Electronic Power Consumption (kWh per Capita)," 2012. http://search.worldbank.org/data?qterm=Electric+Power+ Consumtion + per + capita\&language $=\mathrm{EN} \&$ format $=$ 